\title{
ARTIFICIAL ROOSTS AS SEED DISPERSAL NUCLEI IN A CERRADO AREA IN TRIÂNGULO MINEIRO, BRAZIL
}

\author{
POLEIROS ARTIFICIAIS COMO NÚCLEOS DE DISPERSÃO DE SEMENTES EM \\ UMA ÁREA DE CERRADO NO TRIÂNGULO MINEIRO, BRASIL
}

\author{
Giancarlo Ângelo FERREIRA ${ }^{1}$; Celine de MELO ${ }^{2}$ \\ 1. Biólogo, Universidade Federal de Uberlândia - UFU, Instituto de Biologia INBIO, Laboratório de Ornitologia e Bioacústica - LORB, \\ Uberlândia, MG, Brazil. gianbioufu@ gmail.com; 2. Professora, Doutora, LORB-INBIO-UFU, Uberlândia, MG, Brazil.
}

\begin{abstract}
Vertical artificial structures can serve as artificial roosts attracting birds and increase the seed rain. The purpose of this work was to study the efficiency of different types of artificial roosts as seed dispersal nuclei in a cerrado (Neotropical savannah) area under natural regeneration. Three types of artificial roosts were installed ("X", " $3 \mathrm{X}$ " and "wire") and the species of birds using them and plant species in the seed rain were monitored for a year. The efficiency of the roosts was measured by comparing the seed rain with natural roosts (control). We recorded 760 individuals of 24 species of birds on the artificial roosts. There were more dispersed seeds under artificial roosts than under natural roosts. We collected 607 samples of feces, 569 under artificial roosts (containing 5252 seeds) and 38 under natural roosts (containing 228 seeds). The seeds were of 21 species/morphospecies. The $3 \mathrm{X}$ roost was the most used by birds, but the seed rain was similar between $3 \mathrm{X}$ and $\mathrm{X}$ roosts. We also recorded more seeds under artificial roosts than under natural roosts. Cyanocorax cristatellus (Curl-crested jay), an omnivorous bird, was the most frequent bird recorded at the artificial roosts and seeds of Miconia species were dominant in the seed rain. Artificial roosts were efficient as seed dispersal nuclei and can be adopted as a method to accelerate the regeneration of degraded areas. Research that focuses on artificial roost structure and the factors that influence the seed rain is useful to define targeted and more efficient strategies to habitat restoration.
\end{abstract}

KEYWORDS: Cyanocorax cristatellus. Ecological restoration. Miconia sp. Seed deposition.

\section{INTRODUCTION}

Fragmentation of large natural areas has become an important contributor to increase in degraded areas (BOCCHESE et al., 2008). Flora and fauna are thus exposed to biotic and abiotic environmental changes (GASCON et al., 1999), such as increased distance between forest fragments and reduction of connectivity between areas. Events such as pollination, seed dispersal, reproduction and plant succession, that depend on animals can be affected (GASCON et al., 1999). Seed dispersal is a key element in dynamics of plant populations, because it forms seed and seedling banks which represent the initial phase of forest succession (LOISELLE et al., 1995; CLARK; POULSEN, 2001).

In fragmented landscapes, ecological succession may be impaired by the lack of seeds, but seed deposition can be increased with the use of structures that attract birds (MCCLANAHAN; WOLF, 1987, 1993). Such structures can be natural, such as isolated trees (GUEVARA et al., 1986), artificial trees, wooden posts or dry trees (MCCLANAHAN; WOLF, 1993; GUEDES et al., 1997) distributed in a planned manner in degraded areas. Artificial structures can start a succession process because they increase the local and adjacent floristic composition (MCCLANAHAN; WOLFE, 1987; MELO, 1997; REIS et al., 2010), in turn increasing the structural complexity, and benefiting the interaction between plants and animals (GUEDES et al., 1997).

Specifically, for plants dispersed by birds, the presence of a focal point for landing in vegetation (e.g. roosts) increases seed dispersal and deposition possibilities in soil (HOLL, 1998). The number of seeds dispersed under the roosts can be influenced by the number of landing points (MCCLANAHAN; WOLFE, 1987). Therefore, techniques based on the ecological process of nucleation, defined as the "species' capacity to provide a significant environmental improvement, allowing an increase of this environment occupation probability by other species" (YARRANTON; MORRISON, 1974), have been created to assist ecological restoration. Nucleation creates microhabitats in nuclei suitable for the arrival of species, that increases the local diversity in a successional acceleration process (REIS et al., 2010). One of these techniques is the use of artificial roosts, which is based on restituting the relationships between animals frugivorous and plants in restoration of degraded areas (PALMER et al., 1997). Thus, vertical artificial structures can attract birds and serve as artificial roosts, increasing 
the seed rain. Such roosts can be used as a targeted, low-cost method to restoration (HOLL, 1998; PAUSAS et al., 2006; BOCCHESE et al., 2008).

Our purpose was to evaluate the efficacy of artificial roosts as seed dispersal nuclei in a cerrado area. We expected that the more structurally more complex roosts would attract more birds and consequently increasing the seed rain.

\section{MATERIAL AND METHODS}

\section{Study area}

The study was carried out at Nova Monte Carmelo Farm, owned by the company Duratex S.A., in the state of Minas Gerais, Brazil. The study area has 58,000 ha, dominated by Eucalyptus and Pinus plantation. More than 12,000 ha of the area are constituted by abandoned pastures and forest fragments. Our sampling took place between July 2012 and August 2013 in one area of 200 ha, that is predominantly covered by cerrado in the process of natural regeneration.

\section{Artificial and natural roosts}

Three types of artificial roosts were tested: roosts with an X-shape landing structure $(\mathrm{X})$, roosts with three $\mathrm{X}$-shapes arranged vertically $(3 \mathrm{X})$ and roosts with one horizontal wire (Wire) (Figure 1). The artificial roosts were built with wooden logs of 4-6 $\mathrm{m}$ in length (exposed height), while natural roosts (controls) were live of similar height trees isolated in the surrounding natural vegetation. Under each artificial and natural roost, seed collectors were installed, consisting of waterpermeable rectangle fabrics $(150 \times 80 \mathrm{~cm})$ disposed in north-south or east-west directions. The seed collectors were positioned $40 \mathrm{~cm}$ above the ground, thereby reducing the chance of seed predation by terrestrial invertebrates (BOCCHESE et al., 2008).

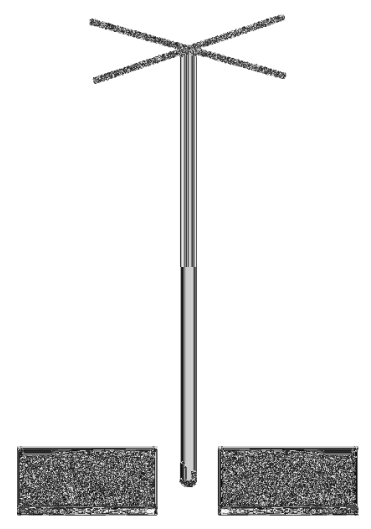

Roost in $\mathrm{X}$ configuration

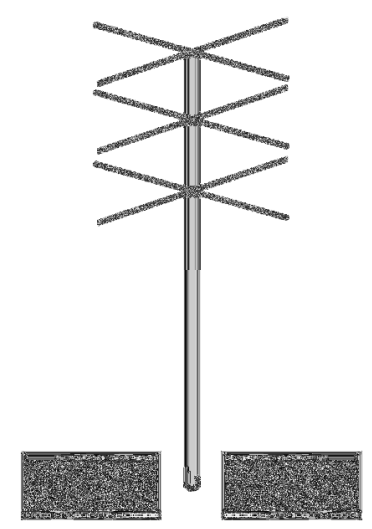

Roost in multiple $\mathrm{X}$ configuration $(3 \mathrm{X})$

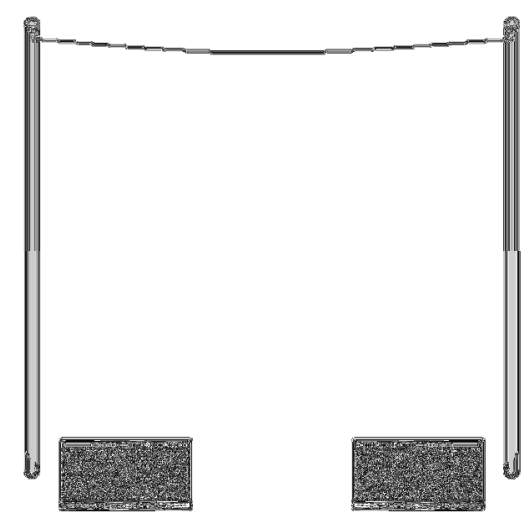

Roost with wire

Figure 1. Types of artificial roosts that were used in this study. Hatched rectangles represent the seed collectors.

\section{Roost distribution}

Roosts were placed in 18 plots of $30 \times 30 \mathrm{~m}$, each separated by a plot of $5 \times 30 \mathrm{~m}$. In each plot $(30 \times 30 \mathrm{~m})$ we erected two $\mathrm{X}$ roosts, one $3 \mathrm{X}$ roost, and one wire roost, totaling 72 roosts. The natural roosts were distributed in the plots of $5 \times 30 \mathrm{~m}$, totaling 18 roosts.

\section{Seed rain monitoring}

Seeds were collected weekly (42 weeks) and stored in individual containers. Subsequently, the material was sorted to separate impurities from seeds and fruits and were identified in the lowest taxonomic level possible.

\section{Use of artificial roosts by avifauna}

The artificial roosts were monitored weekly (6:00-11:00 am or 4:00-6:00 pm), through survey the avifauna that used them. Bird species were characterized according to their general diet (omnivorous, carnivorous, frugivorous, 
insectivorous, nectarivorous and granivorous) (MOTTA-JUNIOR, 1990; SICK, 1997).

\section{Statistical analyses}

Artificial roosts - Analysis of variance (ANOVA) and Tukey test a posteriori were used to investigate possible differences in numbers of birds roosting, numbers of collectors with feces, and the number of seeds in feces among types of roosts. The relationship between number of feces and numbers of birds perched in artificial roosts was evaluated with Pearson's correlation. Furthermore, Shannon diversity index ( $\mathrm{H}^{\prime}$ Index) and similarity indices (Jaccard Index - Sj and Bray-Curtis Index- BC) were calculated for each type of roost. The indices were calculated with the Past program (HAMMER et al., 2001).

Artificial roosts versus natural roosts Student's t-tests were used to analyze whether there was a difference between artificial and natural roosts in the mean number of collectors with feces and the number of seeds present in the feces.

Statistical analyses were carried out in Systat 10.2 (Systat Software Inc. 2002). All statistical tests were carried out at a significance level of 5\% and when necessary, data were transformed in $\log +0.5$. Normality of all data was tested using the Kolmogorov-Smirnov and Lilliefors (test $t$ ) tests and homogeneity of variances of the residues (ANOVA) (ZAR, 1999).

\section{RESULTS}

In 200 hours of observation, 760 individuals of 24 birds species were recorded perching on the artificial roosts. We collected 607 samples of feces, 569 samples from collectors under artificial roosts $(\mathrm{N}=72)$ and 38 from collectors under natural roosts $(\mathrm{N}=18)$. Feces contained 5480 seeds, 5252 $(\overline{\mathrm{x}}=72.94 \pm 120.57$ seeds per roosts) from artificial roosts $(\mathrm{N}=72)$ and $228(\overline{\mathrm{x}}=16.62 \pm 12.66$ seeds per roosts) from the natural roosts $(\mathrm{N}=18)$. The seeds were of 21 species/morphospecies of plants.

\section{Artificial roosts}

Perched birds were more numerous on the $3 \mathrm{X}$ roosts $\left(\mathrm{F}_{2,123}=13.405 ; \mathrm{p}<0.001\right)$. There were difference among artificial roosts in the number of collectors with feces $\left(\mathrm{F}_{2,33}=21.377 ; \mathrm{p}<0.001\right)$ and the monthly average of seeds deposited in collectors $\left(\mathrm{F}_{2,33}=5.105 ; \mathrm{p}=0.012\right)$, december was the month with the highest average. There was not significant correlation between number of collectors with feces and number of birds perched in artificial roosts $(\mathrm{p}=0.068)$.

The community of birds that used the $\mathrm{X}$ and $3 \mathrm{X}$ roosts were similar $(\mathrm{Sj}=0.60 ; \mathrm{BC}=0.71)$; the wire roost hosted the highest species diversity $\left(\mathrm{H}^{\prime}=\right.$ 2.14), followed by $\mathrm{X}\left(\mathrm{H}^{\prime}=1.81\right)$ and $3 \mathrm{X}\left(\mathrm{H}^{\prime}=1.64\right)$ (Table 1).

Tabela 1. Jaccard similarity index $(\mathrm{Cj})$, similarity index of Bray-Curtis $(\mathrm{BC})$ and Shannon diversity index $\left(\mathrm{H}^{\prime}\right)$ being the different types of artificial roosts installed on Nova Monte Carmelo farm.

\begin{tabular}{|c|c|c|c|c|c|c|c|}
\hline Roosts & \multicolumn{3}{|c|}{ Similarity (Jaccard) } & \multicolumn{3}{|c|}{ Similarity (Bray-curtis) } & Diversity \\
\hline & $\mathrm{X}$ & $3 X$ & Wire & $\mathrm{X}$ & $3 X$ & Wire & H' (Shannon) \\
\hline $\mathrm{X}$ & - & 0.6 & 0.48 & - & 0.71 & 0.52 & 1.81 \\
\hline $3 X$ & - & - & 0.5 & - & - & 0.36 & 1.64 \\
\hline Wire & - & - & - & - & - & - & 2.14 \\
\hline
\end{tabular}

\section{Artificial roosts versus natural roosts}

Artificial roosts had a higher number of collectors with feces and more seeds in feces than natural roosts), regarding the number of collectors with feces $(\mathrm{t}=3.948 ; \mathrm{gl}=22 ; \mathrm{p}=0.001)$ and in the number of seeds in feces $(\mathrm{t}=2.397 ; \mathrm{gl}=22$; $\mathrm{p}=0.025)$.

\section{Bird species that used the artificial roosts}

We recorded 24 species of birds in artificial roosts $(\mathrm{N}=72)$ that are classified in seven orders and 12 families. The most frequent species were Cyanocorax cristatellus (Curl-crested jay; 363 records; 47.7\%), Patagioenas picazuro (Picazuro pigeon; 82 records; 10.9\%), and Tyrannus melancholicus (Tropical kingbird; 73 records; 9.6\%). Most of the species recorded were omnivorous $(29.2 \%)$, followed by granivorous species $(25 \%)$ (Table 2).

\section{Seed rain in the collectors}

We recorded 21 species/morphospecies of plants in birds' feces. Seeds of Miconia genus made up $76.5 \%(n=4,192)$ of the total of seeds found in the feces (Table 3). Miconia was represented by Miconia albicans and Miconia fallax, here treated as Miconia spp. because they have morphologically similar seeds and overlap in fruiting period, and Miconia ligustroides. The deposition rate was $28.18 \mathrm{seeds} / \mathrm{m}^{2} /$ year. 
Table 2. List of recorded species on artificial roosts $(\mathrm{N}=72)$, diet according to Motta-Junior (1990) and Sick (1997) and frequency of use on artificial roosts. Nomenclature according to CBRO (2014).Diet: GRA-granivorous, ONI-omnivorous, FRU-frugivorous, INSinsectivorous, CAR-carnivorous, NEC-nectarivorous.

\begin{tabular}{|c|c|c|}
\hline Name of Taxon & Diet & Frequency $(\%)$ \\
\hline \multicolumn{3}{|l|}{ Order Pelecaniformes } \\
\hline \multicolumn{3}{|l|}{ Family Ardeidae } \\
\hline Syrigma sibilatrix & ONI & 1.18 \\
\hline \multicolumn{3}{|l|}{ Family Threskiornithidae } \\
\hline Theristicus caudatus & ONI & 0.26 \\
\hline \multicolumn{3}{|l|}{ Order Accipitriformes } \\
\hline \multicolumn{3}{|l|}{ Family Accipitridae } \\
\hline Rupornis magnirostris & CAR & 0.52 \\
\hline \multicolumn{3}{|l|}{ Order Falconiformes } \\
\hline \multicolumn{3}{|l|}{ Family Falconidae } \\
\hline Milvago chimachima & CAR & 7.6 \\
\hline Herpetotheres cachinnans & CAR & 0.26 \\
\hline Falco femoralis & CAR & 0.39 \\
\hline \multicolumn{3}{|l|}{ Order Columbiformes } \\
\hline \multicolumn{3}{|l|}{ Family Columbidae } \\
\hline Patagioenas picazuro & FRU & 10.9 \\
\hline \multicolumn{3}{|l|}{ Order Apodiformes } \\
\hline \multicolumn{3}{|l|}{ Family Trochilidae } \\
\hline Thalurania furcata & NEC & 0.39 \\
\hline \multicolumn{3}{|l|}{ Order Piciformes } \\
\hline \multicolumn{3}{|l|}{ Family Ramphastidae } \\
\hline Ramphastos toco & ONI & 0.39 \\
\hline \multicolumn{3}{|l|}{ Family Picidae } \\
\hline Campephilus melanoleucos & INS & 0.52 \\
\hline \multicolumn{3}{|l|}{ Order Passeriformes } \\
\hline \multicolumn{3}{|l|}{ Family Tyrannidae } \\
\hline Tyrannus melancholicus & INS & 9.6 \\
\hline Tyrannus albogularis & INS & 0.39 \\
\hline Xolmis velatus & INS & 0.39 \\
\hline \multicolumn{3}{|l|}{ Family Corvidae } \\
\hline Cyanocorax cristatellus & ONI & 47.7 \\
\hline \multicolumn{3}{|l|}{ Family Thraupidae } \\
\hline Tangara cayana & FRU & 0.26 \\
\hline Neothraupis fasciata & ONI & 0.39 \\
\hline Saltatricula atricollis & ONI & 1.05 \\
\hline Sicalis luteola & GRA & 0.26 \\
\hline Emberizoides herbicola & ONI & 2.6 \\
\hline Sporophila nigricollis & GRA & 0.78 \\
\hline Sporophila plumbea & GRA & 0.39 \\
\hline Sporophila sp. & GRA & 0.92 \\
\hline \multicolumn{3}{|l|}{ Family Passerilidae } \\
\hline Zonotrichia capensis & GRA & 4.47 \\
\hline Ammodramus humeralis & GRA & 8.42 \\
\hline
\end{tabular}


Table 3. Species/morphospecies of plants identified by seeds deposited in feces on collectors under artificial and natural roosts.D.S - Dispersal Syndrome (Van der Pijl, 1972).

\begin{tabular}{|c|c|c|c|}
\hline Species/Morphospecies & Family & DS & $\begin{array}{c}\text { Number of } \\
\text { seeds }\end{array}$ \\
\hline Miconia sp. & Melastomataceae & Zoochoric & 2572 \\
\hline Miconia ligustroides & Melastomataceae & Zoochoric & 1620 \\
\hline Illex afins & Aquifoliaceae & Zoochoric & 14 \\
\hline Byrsonima sp. & Malpighiaceae & Zoochoric & 279 \\
\hline Palicourea rigida & Rubiaceae & Zoochoric & 287 \\
\hline Campomanesia adamantium & Myrtaceae & Zoochoric & 214 \\
\hline Psidium sp. & Myrtaceae & Zoochoric & 384 \\
\hline Caryocar brasiliense & Caryocaraceae & Zoochoric & 1 \\
\hline Parinari obtusifolia & Chrysobalanaceae & Zoochoric & 11 \\
\hline Diospyros hispida & Ebenaceae & Zoochoric & 3 \\
\hline Tabernaemontana sp. & Apocynaceae & Zoochoric & 2 \\
\hline Syagrus comosa & Arecaceae & Zoochoric & 1 \\
\hline Morphospecies 1 & & & 2 \\
\hline Morphospecies 2 & & & 2 \\
\hline Morphospecies 3 & & & 10 \\
\hline Morphospecies 4 & & & 2 \\
\hline Morphospecies 5 & & & 39 \\
\hline Morphospecies 6 & & & 2 \\
\hline Morphospecies 7 & & & 33 \\
\hline Morphospecies 8 & & & 1 \\
\hline \multirow[t]{2}{*}{ Morphospecies 9} & & & 1 \\
\hline & & TOTAL & 5480 \\
\hline
\end{tabular}

\section{DISCUSSION}

\section{Artificial roosts}

The $3 \mathrm{X}$ roost was the most used by birds as a landing point compared to the other artificial roosts ( $\mathrm{X}$ and Wire). This result is probably due to high structural complexity of $3 \mathrm{X}$ roost, with more landing points available for birds (HOLL, 1998; MCCLANAHAN; WOLFE, 1987; ROBINSON; HANDEL, 1993). Most of artificial roosts used in previous studies were structurally simpler than the $3 \mathrm{X}$ roost used here (e.g. dry roosts, $\mathrm{X}$ roosts, branches of bamboos, vine towers, and overhead cables); in addition, most previous studies did not monitor the richness and abundance of birds that used the roosts, placing more emphasis on the seed rain (MCDONELL; STILES, 1983; GUEDES et al., 1997; REIS et al., 2010). Melo (1997) used a multiple $\mathrm{X}$ structure (3X) but did not compare it with other types of artificial roosts. We argue that monitoring different roosts and identifying bird species that use them is an important tool in the development of better restoration studies.
Despite the $3 \mathrm{X}$ roost attracted more birds, the number of collectors with feces and the number of seeds collected into them were similar between the $3 \mathrm{X}$ and $\mathrm{X}$ roosts. A bird using the roost does not necessarily regurgitate or defecate, as demonstrated by the lack of correlation between the number of collectors with feces per month and the number of records of birds perched in artificial roosts.

In restoration actions that use artificial roosts as a tool to accelerate the regeneration process and that require a larger supply of propagules, we recommend using both the $3 \mathrm{X}$ and the $\mathrm{X}$ roosts, since both were shown to be equally efficient in seed deposition. These two types of roosts had similar communities of birds, taking into account both richness and abundance of common species to both roosts.

Despite being the most used by birds, the $3 \mathrm{X}$ roosts had lower Shannon diversity index than $\mathrm{X}$ or Wire roosts, due to dominance in the use of this roost by $C$. cristatellus; wich was responsible for over $50 \%$ of the records of birds perched in $3 \mathrm{X}$ roosts. The differential attraction of $C$. cristatellus 
for this type of roost is useful because this specie consumes multiple types of fruits and offers great potential as a seed disperser in the study area.

\section{Artificial roosts versus natural roosts}

Artificial roosts were more efficient in attracting seed rain than natural roosts, both measured by the amount of feces and number of seeds. The vegetation in the study area - cerrado stricto sensu undergoing natural regenerationfeatures bushes and small trees, which makes the installed artificial roosts more attractive to birds that apparently prefer to land on higher roosts (SILVA et al. 2010).Thus, artificial roosts served as landing points, and therefore, seed dispersal hubs for these animals. Similar results were found for artificial roosts in Araucaria forest (ZANINI; GANADE, 2005).

In addition, vegetation structural complexity can influence flight patterns and bird foraging, with more complex structure disproportionately attracting seed dispersers (FITZPATRICK, 1981; MCDONNELL; STILES, 1983; WUNDERLE, 1997). Our artificial roosts increased structural complexity of the study area and attracted frugivorous birds; it is possible that the presence of these structures is more important in seed dispersal than the distance from the propagule source (MCCLANAHAN; WOLFE, 1987; MELO, 1997).

The use of living trees, which are characterized as natural roosts, is also an efficient strategy in recruitment of seeds and seedling establishment (VIEIRA et al., 1994; TOH et al., 1999; CARRIÈRE et al., 2002) and can contribute to the restoration of degraded areas.

We recommend the use of artificial roosts rather than natural roosts in restoration processes once artificial roosts are more attractive and more noticeable in vegetation, especially in terms of height and structure.

\section{Bird species using the roosts}

Most of the bird species recorded in the artificial roosts was omnivorous. These species are important for seed dispersal because they do not have a specialized diet, consuming a variety of fruits of different sizes and shapes, featuring high frequencies of visits and high consumption rates (MOTTA-JUNIOR, 1990; GALETTI; PIZO, 1996).

Omnivorous birds can be strategically important in seed dispersal and natural recovery of degraded areas, because they reduce the dependence of plants to specialized frugivores (GUEDES et al., 1997). In a recent review, omnivores were the main responsible for the consumption of fruits/diaspores of cerrado plants (RIBEIRO et al., 2013). In Brazil, the main related to the early stages of the regeneration process are omnivorous species that inhabit forest edges, scrub, and open anthropized areas (RODRIGUES, 1995; PIZO, 2004, 2007). Within birds, generalist species are the most important for seeds dispersal in open, altered or degraded areas (MCKEY, 1975).

Cyanocorax cristatellus was responsible for almost half of the records of birds perched in artificial roosts. This specie that lives in the countryside and has recently expanded its geographic distribution, with an omnivorous diet of fruits and seeds, small vertebrates and arthropods (SIGRIST, 2012). It is among the birds with larger brain capacity, and can quickly learn to exploit any new food resource in its territory, including Caryocar brasiliense (pequi) (SIGRIST, 2012). This fruit was found in our collectors and is probably dispersed by C.cristatellus, because the large fruit requires large frugivores for dispersal. $C$. cristatellus is potentially a key species in the restoration process of the study area because of its high use of artificial roosts and its generalist use of fruits.

\section{Seed rain in the collectors}

Miconia species, including M. albicans, $M$. fallax and M. ligustroides, represented almost $80 \%$ of the total number of seeds in collectors. The number of species/morphospecies found here maybe is small compared to other studies (MELO, 1997; TOMAZI et al., 2010), however, when it comes to cerrado stricto sensu areas under natural regeneration it is an expressive number of species since this area had great part of its plants still in preproductive phases.

The annual deposition rate of seeds was lower than that found in other studies (TOMAZI et al., 2010). In open areas, there is usually a low supply of fruits, which is related to low food availability and higher risk of predation from birds in these locations. In addition, the surrounding matrix (eucalyptus) may have influenced this process (DUNCAN; CHAPMAN, 2002).

The Melastomataceae family is considered a fundamental group for maintaining the frugivore diversity in tropical forests (GALETTI; PIZO, 1996). A recent review of the species of plants that contribute to the diet of frugivorous birds in the Cerrado identified this family as one of the most important (RIBEIRO et al., 2013).They are considered a key resource in the Cerrado, especially during the dry period because of their year-round fructification (MARUYAMA et al., 2013). In our 
study, seed of $M$. ligustroides was a prominent proportion of the seed collected.

Melastomataceae species can be crucial within a restoration nucleus, due to their earliness in flowering and fructification which attract pollinators and dispersers (COSTA et al., 2013). This rapidly generates appropriate conditions for adaptation and reproduction of other organisms (REIS et al., 2010; KAGEYAMA; GANDARA, 2000). In addition, these species increase connectivity between adjacent fragments, attracting fauna, and thus, may accelerate ecological restoration process (COSTA et al., 2013).

Miconia fruits have attributes that improve dispersal by birds: small size, which does not morphologically restrict the frugivorous seed disperser; abundant fruits, which decrease possible competition between dispersers, and high nutritional availability, which makes the fruit attractive for consumption by its dispersers (GILBERT, 1980; MARUYAMA et al., 2007). Moreover, it has small many seeds that are enclosed within a carbohydrates rich pulp, which would guarantee its dispersal by opportunistic birds (SNOW, 1965, 1981; SICK, 1997; MARUYAMA et al., 2007), providing nutritional balance to omnivorous birds that also feed on invertebrates. Species of Miconia do not offer chemical barriers to digestion (GILBERT, 1980), and are considered a fundamental group for the maintenance of diverse group of frugivores (MANHÃES et al., 2003).

Techniques used for increasing seed rain (e.g. artificial roosts) are usually suggest to work poorly for plants with large seeds (i.e. those with diameter > $15 \mathrm{~mm}$ ) (MARTÍNEZ-GARZA; HOWE, 2003; BARBOSA; PIZO, 2006). In this study, however, even seeds of Caryocar brasiliense, Parinari obtusifolia and Diospyros hispida, all with diameter $>15 \mathrm{~mm}$, were found in seed collectors, showing that the artificial roosts were also efficient for the dispersal of large seeds that require larger frugivores. Large frugivores are rarely found in this study area, precisely because they are the first to disappear from degraded areas with highly reduced and fragmented remnant vegetation (JORDANO et al., 2006).

\section{ACKNOWLEDGEMENTS}

We thank the company Duratex S.A. for financial support for this research.

RESUMO: Estruturas artificiais dispostas verticalmente podem funcionar como poleiros artificiais, atrair aves e incrementar a chuva de sementes. O objetivo deste trabalho foi verificar a eficiência de diferentes tipos de poleiros artificiais como núcleos de dispersão de sementes em uma área de cerrado stricto sensu em processo de regeneração natural. Foram instalados três tipos de poleiros artificiais (X, 3X e Fio) e estes foram monitorados ao longo de um ano em relação às espécies de aves que os utilizarm e espécies de plantas presentes na chuva de sementes. A eficiência destes poleiros foi medida através da comparação da chuva de sementes com poleiros naturais (controle). Foram registrados 760 indivíduos de 24 espécies de aves nos poleiros artificiais. Foram coletadas 607 amostras de fezes, sendo 569 sob os poleiros artificiais (contendo 5252 sementes) e 38 sob os poleiros naturais (contendo 228 sementes). As sementes pertenciam a 21 espécies / morfoespécies de plantas. O poleiro $3 \mathrm{X}$ foi o mais utilizado pelas aves, mas a chuva de sementes foi semelhante entre os poleiros $3 \mathrm{X}$ e X. Havia mais sementes dispersas sob os poleiros artificiais do que sob poleiros naturais. Cyanocorax cristatellus (gralha-do-campo), uma ave onívora, foi a mais frequente utilizando os poleiros artificiais como ponto de pouso. Miconia spp. foram dominantes na chuva de sementes. Poleiros artificiais foram eficientes como núcleos de dispersão de sementes e pode ser adotado como um método para acelerar a regeneração de áreas degradadas. Pesquisas que enfoquem a estrutura dos poleiros artificiais e os fatores que podem influenciar a chuva de sementes sob estes poleiros merecem atenção especial, pois podem definir estratégias direcionadas e mais eficientes para o processo de restauração ambiental.

PALAVRAS-CHAVE: Cyanocorax cristatellus. Deposição de sementes. Miconia sp. Restauração ecológica.

\section{REFERENCES}

BARBOSA, K. C.; PIZO, M. A. Seed rain and seed limitation in a planted gallery forest in Brazil. Restoration Ecology, Washington, v. 14, p. 504-515, 2006. http://dx.doi.org/10.1111/j.1526-100X.2006.00162.x

BOCCHESE, R. A.; OLIVEIRA, A. K.; FAVERO, S.; GARNES, S. J. S.; LAURA, V. A. Chuva de sementes e estabelecimento de plântulas a partir da utilização de árvores isoladas e poleiros artificiais por aves dispersoras de sementes, em área de Cerrado, Mato Grosso do Sul, Brasil. Revista Brasileira de Ornitologia, Belém, v. 16, p. 207-213, 2008. 
CARRIÈRE, S. M.; ANDRÉ, M.; LETOURMY, P.; OLIVIER. I.; MCKEY, D. B. Seed rain beneath remnant trees in a slash-and-burn agricultural system in southern Cameroon. Journal of Tropical Ecology, Winchelsea, v. 18, p. 353-374, 2002.

CBRO (Comitê Brasileiro de Registros Ornitológicos) (2014). Listas das aves do Brasil. 11 a edição.

Downloaded from <http://www.cbro.org.br $>$ on 05/2014.

CLARK, C. J.; POULSEN, J. R. The role of arboreal seed dispersal groups on the seed rain of a lowland tropical forest. Biotropica, Gainesville, v. 33, p. 606-620, 2001. http://dx.doi.org/10.1111/j.17447429.2001.tb00219.x; http://dx.doi.org/10.1646/0006-3606(2001)033[0606:TROASD]2.0.CO;2

COSTA, L. C.; MIRANDA, Z. J.; AQUINO, F. G.; ALBUQUERQUE, L. B.; SOUSA, S. R. Espécies de Melastomataceae juss. com potencial para restauração ecológica de mata ripária no Cerrado. Polibotánica, Cidade do México, v. 35, p. 1-19, 2013.

DUNCAN, R. S.; CHAPMAN, C. A. Limitations of animal seed dispersal for enhancing forest succession on degraded lands. In: LEVEY, D. J.; SILVA, W. R.; GALETTI, M. (Ed.) Seed dispersal and frugivory: ecology, evolution and conservation. CAB International, Wallingford, United Kingdom, 2002. p. 437-450. http://dx.doi.org/10.1079/9780851995250.0437

FITZPATRICK, J. W. Search strategies of tyrant flycatchers. Animal Behaviour, Glenview, v. 29, p. 810-821, 1981. http://dx.doi.org/10.1016/S0003-3472(81)80015-2

GALETTI, M.; PIZO, M. A. C. Fruit eating by birds in a forest fragment in Southeastern Brazil. Ararajuba, Pelotas, v.4, p. 71-79, 1996.

GASCON, C.; LOVEJOY, T. E.; BIERREGARD, R. O. Matrix habitat and richness in tropical forest remnants. Biological Conservation, Boston, v. 91, p. 223-229, 1999. http://dx.doi.org/10.1016/S0006-3207(99)00080-4

GILBERT, L. E. Food web organization and the conservation of neotropical diversity. In: SOULÉ, M. E.; WILCOX, B. A. (Ed) Conservation biology: an evolutionary-ecological perspective. University of Texas Press, Austin, 1980. p. 11-33.

GUEDES, M. C.; MELO, V. A.; GRIFFTH, J. J. Uso de poleiros artificiais e ilhas de vegetação por aves dispersoras de sementes. Ararajuba, Pelotas, v.5, p. 229-232, 1997.

GUEVARA, S.; PURATA, S. E.; VAN DER MAAREL, E. The role of remnant trees in tropical secondary succession. Vegetatio, London, v. 66, p. 77-84, 1986.

HAMMER, O.; HARPER, D. A. T.; RYAN, P. D. PAST - Palaeontological statistics. http://folk.uio.no/ohammer/past/, 2001.

HOLL, K. D. Do bird perching structures elevate seed rain and seedling establishment in abandoned tropical pasture? Restoration Ecology, Washington, v. 6, p. 253-261, 1998. http://dx.doi.org/10.1046/j.1526100X.1998.00638.x

JORDANO, P.; GALETTI, M.; PIZO, M. A.; SILVA, W. R. Ligando frugivoria e dispersão de sementes à biologia da conservação. In: DUARTE, C. F.; BERGALLO, H. G.; DOS SANTOS, M. A.(Ed). Biologia da Conservação: Essências. Editora Rima, São Paulo, Brasil, 2006. p. 411-436.

KAGEYAMA, P. Y.; GANDARA, F. B. Recuperação de áreas ciliares. In: RODRIGUES, R. R.; LEITÃOFILHO, H.; LIMA, M. I. R.; KON, S.(Ed) Matas ciliares: conservação e recuperação.Edusp, São Paulo, Brasil, 2000. p. 249-269.

LOISELLE, B. A.; SORK, V. L.; GRAHAM, C. Comparison of genetic variation in bird-dispersed of tropical wet forest. Biotropica, Gainesville, v. 27, p. 487-494, 1995. http://dx.doi.org/10.2307/2388962 
MANHÃES, M. A.; ASSIS, L. D. S.; CASTRO, R. D. Frugivoria e dispersão de sementes de Miconia urophylla (Melastomataceae) por aves em um fragmento de Mata Atlântica secundária em Juiz de Fora, Minas Gerais, Brasil. Ararajuba, Belém, v. 11, p. 173-180, 2003.

MARTÍNEZ GARZA, C.; HOWE, H. F. Restoring tropical diversity: beating the time tax on species loss. Journal of Applied Ecology, London, v. 40, p. 423-429, 2003. http://dx.doi.org/10.1046/j.13652664.2003.00819.x

MARUYAMA, P. K.; ALVES-SILVA, E.; MELO, C. Oferta qualitativa e quantitativa de frutos em espécies ornitocóricas do gênero Miconia (Melastomataceae). Revista Brasileira de Biociências, Porto Alegre, v. 5, p. 672-674, 2007.

MARUYAMA, P. K.; BORGES, M. R.; SILVA, P. A.; BURNS, K. C.; MELO, C. Avian frugivory in Miconia (Melastomataceae):Contrasting fruiting times promote habitat complementarity between savanna and palm swamp. Journal Tropical Ecology, v. 29, p. 99-109, 2013. http://dx.doi.org/10.1017/S0266467413000138

MCCLANAHAN, T. R.; WOLFE, R. W. Dispersal of ornithochorus seeds from forest edges in Central Florida. Vegetatio, London, v.71, p. 107-112, 1987.

MCCLANAHAN, T. R.; WOLFE, R. W. Acceleration forest succession in a fragmented landscape: the role of birds and perches. Conservation Biology, Washington, v. 77, p. 279-288, 1993.

http://dx.doi.org/10.1046/j.1523-1739.1993.07020279.x

MCDONNELL, M. J.; STILES, E. W. The structural complexity of old field vegetation and the recruitment of bird-dispersed plant species. Oecologia, Munich, v. 56, p. 109-116, 1983.

http://dx.doi.org/10.1007/BF00378225

MCKEY, D. The ecology of coevolved seed dispersal systems. In: Coevolution of animals and plants. University of Texas Press, Austin, 1975. p. 155-191.

MELO, V. A. Poleiros artificiais e dispersão de sementes por aves em uma área de reflorestamento, no Estado de Minas Gerais. 1997. 50 f. Tese (Doutorado em Ciência Florestal) - Curso de Pós-Graduação em Ciência Florestal. Universidade Federal de Viçosa. Viçosa, MG, 1997.

MOTTA-JUNIOR, J. C. Estrutura trófica e composição das avifaunas de três habitats terrestres na região central do estado de São Paulo. Ararajuba, Pelotas, v. 1, p. 65-71, 1990.

PALMER, M. A.; AMBROSE, R. F.; POFF, N. L. Ecological theory and community restoration. Restoration Ecology, Washington v. 5, p. 291-300, 1997. http://dx.doi.org/10.1046/j.1526-100X.1997.00543.x

PAUSAS, J. G.; BONET, A.; MAESTRE, F. T.; CLIMENT, A. The role of the perch effect on the nucleation process in Mediterranean semi-arid old fields. Acta Oecologica, Fribourg, v. 29, p. 346-352, 2006. http://dx.doi.org/10.1016/j.actao.2005.12.004

PIZO, M. A. Frugivory and habitat use by fruit-eating birds in a fragmented landscape of southeast Brazil. Ornitologia Neotropical, v. 15, p. 117-126, 2004.

PIZO, M. A. Frugivory by birds in degraded areas of Brazil. In: DENNIS, A. J.; SCHUPP, E. W.; GREEN, R. J.; WESTCOTT, D. W. (Ed) Seed dispersal: theory and its application in a changing world. CAB International,Wallingford, United Kingdom, 2007. p. 91-110. http://dx.doi.org/10.1079/9781845931650.0615

REIS, A.; BECHARA, F. C.; TRES, D. R. Nucleation in tropical ecological restoration. Scientia Agricola, Piracicaba, v.67, p. 244-250, 2010. http://dx.doi.org/10.1590/S0103-90162010000200018 
RIBEIRO, E. S.; SOUZA, R. S.; MOREIRA, E. L.; PASA, M. C.; DE SOUZA, R. A. T. M. Contribuição das plantas frutíferas do cerrado na dieta das aves e a importância das aves no processo de dispersão de sementes. Biodiversidade, Rondonopólis, v.12, p. 74-89, 2013.

ROBINSON, G. R.; HANDEL, S. N. Forest restoration on a closed landfill: rapid addition of new species by bird dispersal. Conservation Biology, Malden, v. 7, p.: 271-278, 1993. http://dx.doi.org/10.1046/j.15231739.1993.07020271.x

RODRIGUES, M. Spatial distribution and food utilization among tanagers in southeastern Brazil (Passeriformes: Emberizidae). Ararajuba, Pelotas, v. 3, p. 27-32, 1995.

SICK, H. Ornitologia brasileira. 1. ed. Rio de Janeiro: Editora Nova Fronteira, 1997, 862 p.

SIGRIST, T. Iconografia das aves do Brasil: Bioma Cerrado. 1. ed. São Paulo: Editora Vinhedo: Avis Brasilis, 2012, 600p.

SILVA, W. R.; PIZO, M. A.; GABRIEL, W. A. A avifauna como promotora da restauração ecológica. In: VON MATTER, S.; PIACENTINI, V. Q.; STRAUBE, F. C.; CÂNDIDO JR, J. F.; ACCORDI, I. A. (Ed) Ornitologia e Conservação: Ciência aplicada, técnicas de pesquisa e levantamento. Technical Books Editora, 2010, p. 507-516.

SNOW, D. W. A possible selective factor in the evolution of fruiting seasons in tropical forest. Oikos, Munich, v. 15, p. 274-281, 1965. http://dx.doi.org/10.2307/3565124

SNOW, D. W. Tropical frugivorous birds and their food plants: a world survey. Biotropica, Gainesville, v. 13, p. 1-14, 1981. http://dx.doi.org/10.2307/2387865

SYSTAT SOFTWARE Inc. SYSTAT® statistics.Versão 10.2. Richmond. 2002. CD-ROM.

TOH, I.; GILLESPIE, M.; LAMB, D. The role of isolated trees in facilitating tree seedling recruitment at a degraded sub-tropical rainforest site. Restoration Ecology, Washington, v.7, p. 288-297, 1999.

http://dx.doi.org/10.1046/j.1526-100X.1999.72022.x

TOMAZI, A. L.; ZIMMERMANN, C. E.; LAPS, R. R. Poleiros artificiais como modelos de nucleação para restauração de ambientes ciliares: caracterização da chuva de sementes e regeneração natural. Biotemas, Florianopólis, v. 23, p. 125-135, 2010.

VAN DER PIJL, L. Principles of dispersal in higher plants. 1. Ed. Verlag, Berlin, Germany, 1972, 218 p.

VIEIRA, I. C. G.; UHL, C.; NEPSTAD, D. The role of the shrub Cordia multispicata Cham. as a 'succession facilitator' in an abandoned pasture, Paragominas, Amazonia. Vegetatio, London, v. 2, p. 91-99, 1994.

WUNDERLE-JR, J. M. The role of animal seed dispersal in accelerating native forest regeneration on degraded tropical lands. Forest Ecology and Management, Sydney, v. 99, p. 223-235, 1997.

http://dx.doi.org/10.1016/S0378-1127(97)00208-9

YARRANTON, G. A.; MORRISON, R. G. Spatial dynamics of a primary succession: nucleation. Journal of Ecology, London, v. 62, p. 417-428, 194.

ZANINI, L.; GANADE, G. Restoration of Araucaria forest: the role of perches, pioneer vegetation, and soil fertility. Restoration Ecology, Washington, v. 13, p. 507-514, 2005. http://dx.doi.org/10.1111/j.1526-

100X.2005.00063.x

ZAR, J. H. Biostatistical Analysis. 4. ed. Prentice-Hall, New Jersey, 1999, 960p. 